\title{
Which Ballast Water Management System Will You Put Aboard? Remnant Anxieties: A Mini-Review
}

\author{
William R. Batista ${ }^{1, *}$ (D), Flavio C. Fernandes ${ }^{1}$ (D), Claudio C. Lopes ${ }^{2}$, Rosangela S. C. Lopes ${ }^{2}$, \\ Whitman Miller ${ }^{3}$ and Gregory Ruiz ${ }^{3}$ \\ 1 Instituto de Estudos do Mar Almirante Paulo Moreira-IEAPM, Brazilian Navy, Rua Kioto 253, \\ Praia dos Anjos, Arraial do Cabo 28930-000, Brazil; flaviocofe@yahoo.com \\ 2 Laboratório de Síntese e Análise de Produtos Estratégicos-LASAPE/IQ-UFRJ, Av. Athos da Silveira Ramos, \\ 149, Cidade Universitária, Rio de Janeiro 21941-909, Brazil; claudioc@iq.ufrj.br (C.C.L.); \\ sabatini@iq.ufrj.br (R.S.C.L.) \\ 3 Marine Invasions Research Laboratory, Smithsonian Environmental Research Center-SERC, \\ 647 Contees Wharf Road, Edgewater, MD 21037-0028, USA; millerw@si.edu (W.M.); ruizg@si.edu (G.R.) \\ * Correspondence: williamromao12@gmail.com; Tel.: +1-443-482-2241
}

Received: 14 June 2017; Accepted: 31 July 2017; Published: 3 August 2017

\begin{abstract}
An accepted solution to the environmental problems related to a ship's ballast water has been the adoption and proper utilization of approved onboard ballast water plans and management systems (BWMS). On 8 September 2017, the International Maritime Organization Ballast Water Management Convention comes into force, and under this Convention, ships engaged in international trade must have an approved BWMS aboard to discharge ballast water, reducing species transfer. In response to enormous global concern about this problem, the overwhelming majority of the BWMS, approved currently for use by International Maritime Organization (IMO) and United States Coast Guard, utilize two main technologies (electro-chlorination or ultraviolet irradiation) as their principle mode of disinfection, often used in combination with filtration. However, both technologies have been questioned regarding their practically, efficiency, and possible environmental impacts upon discharge. This review article aims to explore some questions about these two technologies, drawing attention to some current uncertainties associated with their use. Also, it draws attention to some technical obstacles and regulatory impediments related to the new development of green biocide technology, which largely has been ignored, despite its potential as a simpler, cleaner and effective technology.
\end{abstract}

Keywords: ballast water treatment; invasive organisms; electro-chlorination; ultraviolet disinfection; green biocide

\section{Introduction}

The unintended relocation of potentially invasive organisms via untreated ballast water, a large volume (sometimes exceeding 50,000 metric tons/vessel) of coastal and ocean water used to maintain the ships' stability and integrity under different operational situations, is a global concern. Such transfers and introductions are a leading cause of biological invasions in coastal environments around the world. The ballast-mediated transfer of organisms is recognized as a challenging, complex, and presently unresolved problem [1-4].

Nowadays, the most widely accepted solution has been the adoption and proper utilization of approved onboard ballast water plan and management systems (BWMS). To this end the International Maritime Organization (IMO) announced that the Ballast Water Management Convention (BWM Convention), drafted in 2004 and now accepted by 52 of 172 IMO member States, will come into force on 8 September 2017, compelling ships engaged in international trade to have an 
approved BWMS onboard [5,6]. Although a significant advance toward mitigating this environmental problem, the majority of the approved BWMS typically rely on physical or chemical modes of action. And, their efficiency, ease of use, and possible environmental impacts are still debated, begging the question as to whether more environmentally friendly, simpler, and lower maintenance alternatives are possible $[7,8]$.

Although an absolute environmentally friendly BWMS does not yet exist, this review aims to explore several questions about the two most commonly used ballast water treatment technology types, electrolytic disinfection and ultraviolet irradiation, drawing attention to some remnant anxieties associated with their use. Also, it draws attention to some uncertainties, technical obstacles, and regulatory impediments related to the development of a green biocide technology, which largely has been ignored, despite its potential as a simpler, cleaner and effective technology.

The authors highlight that the article might provide an update on the progress made in that area, for they have opted to work with a specific subset of available studies with a focus in electrolytic, ultraviolet, and green biocides technologies, and this review is neither a systematic nor an exhaustive work about ballast water treatment.

\section{Regulations and Challenges}

Ballast Water Management Systems (BWMS) are being designed primarily to conform to ballast water standards defined by the regulation D-2 of the BWM Convention and, in the case of the United States of America, the "Standards for Living Organisms in Ships Ballast Water Discharged in U.S. Waters", set by the United States Coast Guard (USCG) as specified in the Code of Federal Regulations $[5,9,10]$.

The D-2 regulation is a discharge standard, which defines the permissible concentration of organisms in ballast water discharge (Table 1), and this standard applies to multiple size classes of organisms. This standard represents a large reduction in the concentration of biota delivered in ballast water, compared to untreated water. Such reduction in propagule pressure (organism delivery) is expected to reduce the establishment of new invasions. And, although based purely on the concept of propagule pressure, one among several factors that affect invasion and establishment of non-native species, these specific size-class discharge standards have been harmonized, accepted, and must be achieved by any vendor seeking official approval for their system $[5,9,11]$.

Table 1. Biological limits to ballast water discharges (IMO D-2 limit values) [5,9].

\begin{tabular}{cc}
\hline Target Organisms & Concentration in the BW Discharge \\
\hline Size $\geq 50 \mu \mathrm{m}$ & $<10$ viable organisms per cubic meter \\
Size $\geq 10 \mu \mathrm{m}$ and $<50 \mu \mathrm{m}$ & $<10$ viable organisms per milliliter \\
Vibrio cholerae (serotypes O1 and O139) & $<1$ (CFU) per 100 milliliter \\
Escherichia coli & $<250(\mathrm{CFU})$ per 100 milliliter \\
Enterococci & $<100(\mathrm{CFU})$ per 100 milliliter \\
\hline
\end{tabular}

IMO: International Maritime Organization; BW: ballast water; CFU: colony forming units.

BWMS technologies must overcome a myriad of specific design and construction requirements related to these regulations, where the primary hurdle is defined by the biological performance tests, to evaluate whether the BWMS meets the specific concentration-based discharge standards. BWMS also must attain official approval or certification prior to installation and use on ships [12,13].

In the midst of these regulatory activities, the IMO's recent announcement highlights the importance of development, testing, and implementation of BWMS by the engineering and shipping industries. However, from the manufacturing and implementation points of view, the development, testing, installation, and everyday use of officially approved BWMS is a complicated and lengthy process. In fact, performance specifications are critical points for the design, engineering, construction, and operational requirements of BWMS. Therefore, any uncertainty about the performance standards 
that a BWMS must achieve could greatly to complicate the effective development and the implementation of such systems [14].

At this stage, there is broad international agreement on regulation D-2 discharge standards from IMO, providing the industry with a relatively solid design target. However, in addition to biological concentration standards, all BWMS must meet safety and environmental impact standards too (e.g., the safety of ship and crew and the chemical release to surrounding waters). To complicate matters, despite IMO advice for signatory countries to not penalize those "early adopters" who have installed first-generation BWMS, manufacturers must keep in mind the possibility that performance standards and regulations may become more stringent in the future. So, given the operational life of ships, manufacturers and shipping companies must adopt a long-term view of ballast water treatment, yet seek to comply with current ballast water discharge standards $[15,16]$.

As described, the challenges to designing a BWMS with available technology are many fold. BWMS must be accommodated by different types of ships, effective for different classes of organisms (including their various and distinct life stages), and operate efficiently and safely under widely varying ballast water conditions (e.g., ranges of salinities, temperatures, and flow rates). Although future innovation and cutting-edge technologies are often viewed as the most attractive approaches to solving such problems, existing technologies must not be overlooked. Ballast water technologies must be well grounded in basic and well-known physical, chemical, and biological principles, and they must also conform to essential characteristics required for onboard commercial technology, i.e., a system that is technically feasible, environmentally acceptable, practical (easy training, operation, and maintenance), operationally safe, and, of course, of acceptable final cost [17].

Under ordinary operating conditions, there are still uncertainties about the reliability, longevity, and biocidal performance of an approved BWMS after being commissioned. In this context, a recent study conducted by Bakalar et al. concluded that some type approved BWMS, despite proper installation on evaluated ships, have been unsatisfactorily operated, monitored, and, in the worst case, by-passed altogether [18]. Similar conclusions were drawn by the 2015 final report from Marine Environment Protection Committee [19]. Thus, regardless of the technical potential of a BWMS to meet discharge standards, including even initial performance tests that meet D-2 standards, real world onboard conditions and human behavior can present limitations to a system's practicability (i.e., training, operation, and maintenance), which in some cases can undermine the effectiveness of a BWMS.

Looking to the future, such practicability limitations could also plague more stringent discharge standards. The USCG has approved its first BWMS in 2016 but also stated in its "Practicability Review" of 10 May 2016 that it knows of no available technology capable of meeting discharge standard more stringent than current D-2 standards [20,21]. Related to such practicability issues, on 8 October 2015, the state of California approved a State bill delaying the implementation date for its final (more stringent) performance standard of zero detectable living organisms to 1 January 2030, due to lack of available technology that can meet this performance [22]. There is, however, disagreement about the current capability and performance of available technologies. For example, in contrast to USCG and California State releases, Cohen et.al concluded that some existing BWMS can meet limits until 100 times more stringent than those in regulation D-2 [23].

As indicated in IMO's 2015 final report, among those approved and commercially available BWMS used for reducing organisms concentration in ballast water, filtration devices are included in almost $80 \%$ of treatment approaches used by the ships evaluated, electrolytic disinfection devices in almost $40 \%$, ultraviolet (UV) irradiation devices in $32 \%$, and the use of liquid hypochlorite are found in almost $17 \%$ of systems. Acoustic devices, heat procedures, mechanical or chemical deoxygenating, and other less frequently applied alternative technologies were represented negligibly [19].

Currently, most approved BWMS and systems in the test phase tend to operate using a combination of filtration followed by chemical treatment (e.g., electro-chlorination, the addition of active substances), or physical oxidation using UV irradiation [24,25]. The filtration stage aims to retain 
and to remove organisms and suspended matter from ballast water, normally limited to size classes above $50 \mu \mathrm{m}$ in maximum dimension. In contrast, both chemical treatment and physical oxidation stages have distinct principles of action. While the first acts by disrupting cellular membranes and other cellular components, the latter induces damage directly to cell's deoxyribonucleic acid and proteins [26]. The objectives of these approaches are to either outright kill the organisms present in the ballast water or to damage them sufficiently to render them not viable (i.e., lacking the biological capacity to live, develop and reproduce), to achieve biological discharges standards.

\section{Remnant Anxieties Related to Two Main Technologies}

\subsection{Using UV Irradiation}

An apparent advantage of ballast water management systems (BWMS) that use filtration followed by UV irradiation is that the environmental pollution footprint of the process is minimized since, supposedly, no chemicals or chemical byproducts are released into the surrounding waters. However, Culin and Mustac have identified possible unexpected disinfection by-products, organohalogens compounds, and aldehydes [27]. Although UV treatment typically does not require secondary treatment to neutralize chemical activity prior to discharge, thereby minimizing unintended environmental impacts, these types of systems generally require meticulous operation and maintenance [18].

Additionally, they may require significantly greater electric power capacity to accommodate large flow rates and sufficient electrical supply to power UV components. In fact, estimated energy budgets for UV irradiation can range from 60 to $200 \mathrm{kWh}$ per $1000 \mathrm{~m}^{3}$ of ballast water treated [25], and they are also plagued by significant losses in efficiency when high dissolved organic matter or high turbidity is present in the ballast water intake [28].

First and Drake have stressed the necessity for correct irradiation dosage versus uninterrupted irradiation to overcome cellular repair mechanisms in target organisms, indicating that UV radiation may be incapable of destroying some microorganisms, such as bacterial spores and microalgae [29,30].

With respect to the efficacy of UV radiation, laboratory assays using three size classes of living marine planktonic organisms, the investigators showed UV treatments were ineffective at reducing concentrations to acceptable discharge standards [31]. Furthermore, tests using microalgae showed that, after a combination of UV treatment and dark storage, significant subsequent regrowth under light exposure occurred and was directly dependent on the UV dose applied [32]. Grob and Pollet [33] highlighted problems related to potential regrowth of resistant microorganisms in ballast water, and diatoms, frequently the most common and abundant phytoplankton in the seawater, have also proven to be very resistant to UV treatment [34,35].

Because UV irradiation does not immediately kill many microorganism types, the issue of the viable vs. living condition is raised. So, when immediate mortality is not directly induced, the true efficacy of a BWMS must be evaluated based on whether or not the biota in ballast water has been damaged enough to prevent proper growth, development, and reproduction following UV treatment [36-38].

Indeed, the lag time between exposure and death or reproductive impairment introduces complicating factors for BWMS testing and evaluation. Such issues raise technical questions related to viability assessment methods used and that have been debated extensively. To address such issues, the USCG has determined that traditional regrowth assay using the most probable number test, in replacement of vital stain tests, will not be accepted as an accurate method for determining the number of the viable organism in the size range of $\geq 10 \mu \mathrm{m}$ and $<50 \mu \mathrm{m}$ [39]. In the absence of a rapid but accurate, viability assessment methodology, such a ruling may significantly hamper the approval of some UV irradiation BWMS by the USCG. 


\subsection{Using Electrolytic Disinfection}

The use of electrolytic disinfection (electro-chlorination) relies on the generation of the chlorine gas $\left(\mathrm{Cl}_{2(\mathrm{~g})}\right)$, which reacts with water to produce hypochlorous acid $(\mathrm{HOCl})$, both active substances with powerful oxidant action [40,41]. The chemical reactions associated with these BWMS (Table 2) show that this process is dynamically dependent on both the molar concentration of hydrogen ions $\left[\mathrm{H}^{+}\right]$and the molar concentration of chlorine ions $\left[\mathrm{Cl}^{-}\right]$existing in the ballast water under treatment.

Natural seawater has, with some variation, a pH typically around 8 [42], and, consequently, a low $\left[\mathrm{H}^{+}\right]$available to react. Based on both the dissociation reaction of the $\mathrm{HOCl}$ (Table 2) and Le Chatelier's principle, the formation of $\mathrm{HOCl}$ will be diminished because of a shift of equilibrium toward the formation of hypochlorite ion $\left(\mathrm{OCl}^{-}\right)[43,44]$; and, given that $\mathrm{OCl}^{-}$is a disinfectant agent several times less active than $\mathrm{HOCl}$, it is expected that electro-chlorination efficiency of natural seawater always will be impaired due its relatively low $\left[\mathrm{H}^{+}\right]$.

Table 2. Electrolytic disinfection chemical process [43,44].

\begin{tabular}{|c|c|}
\hline Process & Chemical Reactions \\
\hline Solvation & $\mathrm{NaCl}_{(s)}+\mathrm{H}_{2} \mathrm{O}_{(l)} \rightarrow \mathrm{H}_{(a q)}^{+}+\mathrm{OH}_{(a q)}^{-}+\mathrm{Na}_{(a q)}^{+}+\mathrm{Cl}_{(a q)}^{-}$ \\
\hline $\begin{array}{l}\text { Electrolysis: } \\
\text { (cathode) } \\
\text { (anode) }\end{array}$ & $\begin{array}{l}2 \mathrm{H}^{+}{ }_{(a q)}+2 e^{-} \rightarrow \mathrm{H}_{2(g)} \\
2 \mathrm{Cl}^{-}{ }_{(a q)} \rightarrow \mathrm{Cl}_{2(g)}+2 e^{-}\end{array}$ \\
\hline Hydrolysis & $\mathrm{Cl}_{2(g)}+\mathrm{H}_{2} \mathrm{O}_{(l)} \rightarrow \mathrm{HOCl}_{(a q)}+\mathrm{H}_{(a q)}^{+}+\mathrm{Cl}_{(a q)}^{-}$ \\
\hline Dissociation & $\begin{array}{c}\mathrm{HOCl} \rightleftharpoons \mathrm{H}^{+}+\mathrm{OCl}^{-} \\
\text {Dissociation constant, } K_{a(\mathrm{~T})}=\frac{\left[\mathrm{H}^{+}\right]\left[\mathrm{OCl}^{-}\right]}{[\mathrm{HOCl}]}\end{array}$ \\
\hline Carbonation & $\mathrm{CO}_{2(g)}+\mathrm{H}_{2} \mathrm{O}_{(l)} \rightleftharpoons \mathrm{H}_{(a q)}^{+}+\mathrm{HCO}_{3}{ }_{(a q)}$ \\
\hline
\end{tabular}

Actually, the $\mathrm{pH}$ problem related to the effectiveness of electro-chlorination in natural seawater raises additional technical concerns, and additional procedure, such as carbonation (reaction showed Table 2), i.e., direct injection of carbon dioxide gas $\left(\mathrm{CO}_{2}\right)$ into ballast water is used to maintain low ballast water $\mathrm{pH}$, i.e., higher $\left[\mathrm{H}^{+}\right][45]$. However, extra and necessary equipment must be properly installed and the process controlled and monitored. Ultimately, the cost and efficacy of electro-chlorination disinfection must be fully considered when attempting to understand the process's efficacy.

On the other hand, problems related to $\left[\mathrm{Cl}^{-}\right]$are directly correlated with lower salinities, conditions that are common in the upper reaches of many estuaries and in freshwater ecosystems. Lower $\left[\mathrm{Cl}^{-}\right]$will produce lower formation $\mathrm{Cl}_{2}$ in the anode area and consequently produce lower disinfection efficiency when compared to most saline water. Indeed, this is a real problem that requires the use of specific electrode materials as well as an increase in electric power consumption to generate adequate concentrations of total residual oxidants [46,47].

The aforementioned factors are not the only ones affecting the efficiency of the electrolytic disinfection process. Ballast water temperature is also an important and frequently ignored factor that is directly related to the equilibrium dissociation constant $\left(K_{a(\mathrm{~T})}\right)$-lower temperatures decrease the molar concentration of hypochlorous acid [HOCl] favoring the existence of $\mathrm{OCl}^{-}$species [48]. Additionally, the presence of other naturally occurring anion species in seawater compete in the anode area and impair the efficiency of this process. For example, bromide anions, in conjunction with dissolved organic material, can generate very harmful by-products (e.g., different brominated compounds and tri-halomethanes), which can contribute to increased levels of hazardous disinfection byproducts during deballasting $[43,49,50]$. 
Yet another important complicating aspect of electro-chlorination procedures is the possibility of accelerated rates of carbon steel corrosion due to the corrosive action of oxidizing agents, such as $\mathrm{Cl}_{2}$, $\mathrm{HOCl}$, and $\mathrm{ClO}^{-}$produced during the treatment $[51,52]$. Indeed, appropriate corrosion testing has been recommended by the IMO to BWMS applicants, as a precautionary measure (despite the inconclusive or contradictory nature of findings to date), since increased rates of corrosion have the potential to intensify structural failures in ballast tanks and pipelines, thus compromising the structural integrity of the ship [12]. The consequence, of such added testing, is a further increase in the cost of maintenance and preventive corrosion protection, i.e., paint and sacrifice anodes [53].

\section{Using Biocides as Active Substances}

The term biocide defines any product used to control organisms harmful to human, animal and vegetal health, or that may cause damage to materials and equipment. Biocides can contain or generate one or more active substances, and usually, they are classified into 4 main groups: disinfectants, pesticides, preservatives, and others biocidal products [54,55].

In the context of ballast water treatment, an active substance is defined as any substance or organism specifically used against nuisance aquatic organisms and pathogens present in the ballast water, and a relevant chemical is defined as any reaction product that is hazardous to human health and/or the environment. Both, active substances and relevant chemicals can be produced before or during ballast water treatment, and in the worst case, in the environment of the discharge site $[15,56]$.

Without exception, to officially gain recognized approval, any ballast water management systems (BWMS) that make use of active substances or produces relevant chemicals must comply with all associated environmental regulations. The IMO guideline G-9, Procedure for Approval of Ballast Water Management Systems that make use of active substances, as well as the rules testing and evaluation requirements for active substances, preparations and relevant chemicals, and test report requirements, respectively subparts 162.060-32 and 162.060-36, Title 46 of the United States Code of Federal Regulations, establish that such chemicals must be deemed acceptable and safe via additional testing that demonstrates the substances are not bioaccumulative, not persistent in the environment, and not toxic to humans $[12,15,56]$.

Legislative and public acceptance, cost/benefit and risk evaluation, shipboard safety, and practicality are also important factors that affect the use of biocides. In the case of new biocide candidates, such requirements are even more problematic, since thorough testing to characterize their chemical nature and activity must be completed before any real world tests are possible [57].

As a rule, those additional requirements are laborious, time-consuming, and expensive, but they are mandatory, according to internationally recognized standards and testing regulations/guidelines. Perhaps for this reason, during the last ten years, only 41 BWMS classified as using active substance have received final approval of use by the IMO. Among these approved systems, there is not a single system using a living organism for biological control, and only 11 systems using simple addition of chemical substances: peracetic acid (3 systems), sodium hypochlorite (2), calcium hypochlorite (1), sodium chlorate (1), sodium dichloroisocyanurate (3), and polyaluminiun chlorohydrate (1 system). However, it is important to note that none of these systems use an environmentally friendly or a "green biocide", and the remaining approved systems use much more complex operational process, such as electro-chlorination (21 systems), associated UV irradiation (6) and Ozone generation (3 systems) [58].

An environmentally friendly or a green biocide has as cornerstone principle the use of green chemistry, i.e., to be produced from least toxic and renewable raw material using a more economical synthesis process, to cause minimal or no harm to the environment, and do not be hazardous to human health $[59,60]$.

Indeed, except for the peracetic acid, few biocides without metal or halogen components in their composition have been suggested for testing in BWMS. Among them, only two commercial products have actually undergone rigorous testing, Mexel ${ }^{\circledR} 432$ and SeaKleen ${ }^{\circledR}$. Mexel 432 has as active substance a mixture of alkylamines, CAS No. 61791-63-7, and possesses an anionic surfactant 
action. It has been used as an antifouling agent to prevent fouling development in cooling water systems. Although considered an efficient molluscicide, Mexel 432 has been characterized by its toxicity at very low concentrations [61-64]. SeaKleen ${ }^{\circledR}$ has as active substance a synthetic naphthoquinone, CAS No. 58-27-5, also known as Menadione, a polycyclic aromatic compound that has been used as anti-hemorrhagic animal feed additive $[65,66]$.

A study comparing the actions of the peracetic acid with these two biocides shows that although peracetic acid was more efficient against bacteria, Seakleen and Mexel 432 were more efficient against phytoplankton and zooplankton [67].

The peracetic acid, CAS No. 79-21-0, has been used in BW treatment in association with hydrogen peroxide in different proportions. Even though this mixture is free from metal or halogenated substance, the peracetic acid is corrosive to metallic structures [68,69], besides being considered an unstable, flammable, and irritating substance [70].

Although the idea of a green biocide that lacks metal or halogen substances, is readily biodegradable, and does not persist in the environment (including low bioaccumulation patterns) may seem attractive, the BWMS industrial segment has not moved in this direction. Indeed, the absence of an efficient and environmentally friendly biocide also has been a significant problem faced by the shipping industry when considering how to prevent biofouling on the outside of hulls, another recognized vector associated with the undesirable relocation of potentially invasive organisms. To date, the marine coating industry as a whole has not invested in developing environmentally friendly natural biocides [71,72]. Nevertheless, environmentally friendly natural biocide compounds may hold great promise, both for BWMS and hull fouling prevention.

\section{Discussion}

Over the last thirty years, there have been countless discussions and deliberations by regulatory bodies, scientists, and industry on the nature and extent of economic impacts associated with the growing number of marine invasive species around the world [73]. It is of great concern that there are still so few available technologies designed to treat ballast water. Indeed, among the ballast water management systems (BWMS) available today, the technologies that are currently in use can be categorized primarily into two basic types: (1) filtration plus ultraviolet irradiation and (2) filtration plus electro-chlorination [74]. Regardless of their market share, there still remain unanswered technical questions and uncertainties about these systems' genuine efficacy and robustness for organism reduction across the full spectrum of operational and environmental conditions.

The situation is surprising when one realizes that an entire century has passed since Nicolaus Peter and Albert Panning wrote their early conjectures about ballast water as a possible vector in the dispersion of the Chinese Mitten crab Eriocheir sinensis in Europe [75]. Indeed, it has been more than 40 years since definitive evidence of aquatic invader transfer across long distances by means of ballast water was scientifically documented [76].

In general, potentially simpler BWMS that use an ordinary biocide addition process and run less complicated equipment that requires little maintenance and monitoring, have been overlooked by BMWS manufacturers and are largely unavailable [17]. Although this reticence is likely due to the current absence of a safe, environmentally friendly, and economical chemical with the capacity to be used as an active substance, it is possible that other factors also play into a hesitation to pursue such technologies $[57,60]$.

The perceived financial risk-to-reward ratio may be a deterrent, compared to the application (modification) of existing technologies for municipal water treatment. For example, there are often relatively meager yields compared to enormous investments by pharmaceutical companies attempting to identify and isolate potential drugs from nature. The experience of such limited results suffered by pharmaceutical industry, which has invested in extensive and continual research to identify, to isolate, and to industrialize naturally occurring chemical substances, may have indirectly contributed to the lack of investments in the prospection and use of natural products by shipping industry [77]. 
Nevertheless, even though a myriad of natural bioactive substances are being discovered and published every year [78,79], natural biocide compounds are generally too complex to synthesize, and the greatest obstacle to producing green biocides at large scale and mass production levels are the technical challenges associated with developing practicable methods of synthesis that can scale to metric tonnes of output $[80,81]$.

In fact, the transfer of living organisms in ballast water remains an unresolved environmental problem worldwide, but choosing an effective BWMS to put aboard is also a big and onerous challenge. While recognizing that there is not a miraculous treatment system that can overcome the whole problem just around the corner, it is possible to agree that an environmentally friendly system running simpler equipment, requiring low maintenance, and easy operation could be the best and first option. In fact, the use of onboard BWMS has great potential to be a truly global solution to a global problem. Since ships that operate onboard BWMS have the potential to protect all coastal waters of all countries, not just the most economically advantaged countries, this engineering solution represents a socially just solution to a shared environmental challenge. However, there remain several sources of uncertainty about which technologies will be part of this solution, and their relative merits and constraints.

Whether due to regulatory uncertainty, perceived costs, or public concern, the relatively slow pace of technological innovation has contributed to the current limited ability to accurately identify and rapidly advance BWMS mechanisms that hold the greatest promise to address this environmental problem. At the same time, the urgency for a solution is all the more amplified by the impending September 2017 regulatory deadline faced by the commercial shipping industry.

Even general apprehension about the use of biocide substances, by society and regulatory bodies, may also contribute to the current lack of action and innovation in this field, this absence of innovation is paradoxical. In fact, biocides are used extensively for agriculture, drinking water, and sewage treatment, activities that affect large portions of the global population and represent enormous economic investments, costs that far outstrip any potential investment costs borne by the commercial shipping industry. Fortunately, in spite of very little resource allocation (when compared with the amount spent on environmental remediation) researchers have relentlessly continued their assessments and investigations of green biocides, as well as other possible alternative technologies, for potential use as approved BWMS. Needless to say, without greater vision and financial support from industrial sectors, the necessary research and development of such technologies will be slowed significantly.

\section{Conclusions}

Despite various doubts related to regulatory requirements, reliability, and efficacy of currently available technologies, the use of ballast water management systems (BWMS) is a widely accepted and established solution for mitigating invasion risks associated with ballast water. Robust, high efficiency, simpler principle, environmentally friendly, low maintenance, and easy use are the most desired characteristics of a BWMS. Some uncertainties and anxieties still exist about existing technologies, raising the question to whether a more environmentally and crew friendly technology is possible. While improvement of the currently available technologies is actively underway, innovation and development of green and environmentally friendly biocides should advance also to meet both short and long-term goals, to minimize both invasion risks and environmental impacts. Given that the actual performance of early onboard BWMS remains uncertain, there is still room to develop, test, and implement a range of new BWMS technologies to effectively reduce the release of invasive marine species. We suggest that future research should include deeper exploration of green technologies, aiming to advance environmentally friendly systems with simple equipment and maintenance needs, easy operations, and low uncertainty about environmental impacts. While all this is going on, it is time to choose a BWMS to put aboard.

Acknowledgments: The authors are grateful for infrastructural support from Smithsonian Environmental Research Center-SERC, Marinha do Brasil (Brazilian Navy), and Universidade Federal do Rio de Janeiro (Federal University at Rio de Janeiro). 
Author Contributions: This work is a collaborative effort where all authors contributed to the conception, the writing and the review of the paper.

Conflicts of Interest: The authors declare that they have no conflict or competing financial interest. There is no funding sponsor.

\section{References}

1. Bailey, S. An overview of thirty years of research on ballast water as a vector for aquatic invasive species to freshwater and marine environments. Aquat. Ecosyst. Health 2015, 18, 261-268.

2. Ruiz, G.M.; Fofonoff, P.W.; Steves, B.P.; Carlton, J.T. Invasion history and vector dynamics in coastal marine ecosystems: A North American perspective. Aquat. Ecosyst. Health 2015, 18, 299-311.

3. Carney, K.J.; Minton, M.S.; Holzer, K.K.; Miller, A.W.; McCann, L.D.; Ruiz, G.M. Evaluating the combined effects of ballast water management and trade dynamics on transfers of marine organisms by ships. PLoS ONE 2017, 12, e0172468. [CrossRef] [PubMed]

4. Davidson, I.C.; Minton, M.S.; Carney, K.J.; Miller, A.W.; Ruiz, G.M. Pioneering patterns of ballast treatment in the emerging era of marine vector management. Mar. Policy 2017, 78, 158-162. [CrossRef]

5. International Maritime Organization (IMO). International Convention for the Control and Management of Ships' Ballast Water and Sediments; International Maritime Organization (IMO): London, UK, 13 February 2004.

6. International Maritime Organization (IMO). International Convention for the Control and Management of Ships' Ballast Water and Sediments; International Maritime Organization (IMO): London, UK, 8 September 2016.

7. Balaji, R.; Yaakob, O.; Koh, K.K. A review of developments in ballast water management. Environ. Rev. 2014, 22, 298-310. [CrossRef]

8. David, M.; Gollasch, S. Vessels and ballast water. In Global Maritime Transport and Ballast Water Management (Invading Nature Springer Series in Invasion Ecology); Springer: Berlin, Germany, 2015; pp. 13-34.

9. United States Coast Guard (USCG). Standards for Living Organisms in Ships' Ballast Water Discharged in U.S. Waters. Available online: http:/ / www.worldshipping.org/industry-issues/environment/vesseldischarges/USCG_BW_Final_Rule.pdf (accessed on 23 May 2016).

10. United States Code of Federal Regulations (CFR). CFR Part 151, Subpart D—Ballast Water Management for Control of Nonindigenous Species in Waters of the United States. Available online: https:/ /www.law. cornell.edu/cfr/text/33/part-151 (accessed on 31 July 2017).

11. National Research Council (NRC). Assessing the Relationship between Propagule Pressure and Invasion Risk in Ballast Water; National Academy of Sciences: Washington, DC, USA, 2011; p. 156, ISBN 978-0-309-21562-6.

12. International Maritime Organization (IMO). Guidelines for Approval of Ballast Water Management Systems (G8). Available online: http://www.imo.org/en/KnowledgeCentre/IndexofIMOResolutions / Marine-Environment-Protection-Committee\%28MEPC\%29/Documents/MEPC.174\%2858\%29.pdf (accessed on 31 July 2017).

13. United States Environmental Protection Agency (USEPA). Generic Protocol for the Verification of Ballast Water Treatment Technology; USEPA: Washington, DC, USA, 2010.

14. Stubbs, J.T. Ballast water treatment: Urgent practical results needed. In Proceedings of the 6th GEF-UNDP-IMO GloBallast R\&D Forum and Exhibition on Ballast Water Management Ballast Water Management Convention: Moving towards Implementation, Montreal, QC, Canada, 16-18 March 2016; pp. 35-37.

15. United States Code of Federal Regulations (CFR). 46 CFR Part 162, Subpart 162.060—Ballast Water Management Systems. Available online: https://www.law.cornell.edu/cfr/text/46/part-162/subpart162.060 (accessed on 31 July 2017).

16. Linders, G. The GESAMP-BWWG methodology: A living document. In Proceedings of the 6th GEF-UNDP-IMO GloBallast R\&D Forum and Exhibition on Ballast Water Management Ballast Water Management Convention: Moving towards Implementation, Montreal, QC, Canada, 16-18 March 2016; pp. 43-45.

17. National Research Council (NRC). Stemming the Tide: Controlling Introductions of Nonindigenous Species by Ship's Ballast Water; National Academies Press: Washington, DC, USA, 1996; p. 160, ISBN 0-309-58932-0.

18. Bakalar, G. Comparisons of interdisciplinary ballast water treatment systems and operational experiences from ships. SprigerPlus 2016, 5, 1-12. [CrossRef] [PubMed] 
19. International Maritime Organization (IMO). Harmful Aquatic Organisms in Ballast Water. Available online: https: / / docs.imo.org/Search.aspx?keywords=\%22MEPC\%2069\%2F4\%2F4\%22 (accessed on 31 July 2016).

20. United States Coast Guard (USCG). Practicability Review: Standards For Living Organisms in Ship's Ballast Water Discharged in the United States Waters. Available online: http: / / mariners.coastguard.dodlive.mil/2016/05/11/5112016-practicability-review-standards-for-livingorganisms-in-ships-ballast-water-discharged-in-u-s-waters / (accessed on 31 July 2016).

21. United States Coast Guard (USCG). Marine Safety Information Bulletin Nr 14. Available online: https: / / www.uscg.mil/msib/docs/014_16_12-2-2016.PDF (accessed on 31 January 2017).

22. California Legislative Information (CLI). Assembly Bill No. 1312. CHAPTER 644. 2015. Available online: http:/ /leginfo.legislature.ca.gov/faces/billNavClient.xhtml?bill_id=201520160AB1312 (accessed on 22 July 2016).

23. Cohen, A.N.; Dobbs, F.C.; Chapman, P.M. Revisiting the basis for US ballast water regulations. Mar. Pollut. Bull. 2017, 118, 348-353. [CrossRef] [PubMed]

24. CLASSNK Nippon Kaiji Kyukai (Japan). Latest Information of Approval of BWMS. Available online: https://www.classnk.or.jp/hp/pdf/activities/statutory/ballastwater/approval_ballast_e.pdf (accessed on 28 July 2016).

25. Lloyd's Register Group. Available Ballast Water Treatment Systems. Available online: http://www.lr.org/ en/services/environment-and-sustainability/ballastwatermanagement.aspx (accessed on 28 June 2016).

26. United States Environmental Protection Agency (USEPA). Ultraviolet Disinfection Guidance Manual for the Final Long Term 2 Enhanced Surface Water Treatment Rule; USEPA: Washington, DC, USA, 2006.

27. Culin, J.; Mustac, B. Environmental risks associated with ballast water management systems that create disinfection by-products (DBPs). Ocean. Coast. Manag. 2015, 105, 100-105. [CrossRef]

28. Werschkun, B.; Banerji, S.; Basurko, O.C.; David, M.; Fuhr, F.; Gollasch, S.; Grummt, T.; Haarich, M.; Jha, A.N.; Kacan, S.; et al. Emerging risks from ballast water treatment: The run-up to the international ballast water management convention. Chemosphere 2014, 112, 256-266. [CrossRef] [PubMed]

29. First, M.R.; Drake, L.A. Life after treatment: Detecting living microorganisms following exposition to UV light and chlorine dioxide. J. Appl. Phycol. 2014, 26, 227-235. [CrossRef]

30. First, M.R.; Drake, L.A. Approaches for determining the effects of UV radiation on microorganisms in ballast water. Manag. Biol. Invasions 2013, 4, 87-99. [CrossRef]

31. First, M.R.; Wamsley, S.H.R.; Riley, S.C.; Drake, L.A. Towards minimizing transport of aquatic nuisance species in ballast water: Do organisms in different size classes respond uniformly to biocidal treatment? Biol. Invasions 2016, 18, 647-660. [CrossRef]

32. Martinez, L.R.; Andres, J.M.; Merino, A.A.; Nebot, E. Evaluation of ultraviolet disinfection of microalgae by growth modeling: Application to ballast water treatment. J. Appl. Phycol. 2016, 28, 2831-2842. [CrossRef]

33. Grob, C.; Pollet, B.G. Regrowth in ship's ballast water tanks: Think again! Mar. Pollut. Bull. 2016, 109, 46-48. [CrossRef] [PubMed]

34. Liebich, V.; Stehouwer, P.; Veldhuis, M. Re-growth of potential invasive phytoplankton following UV-based ballast water treatment. Aquat. Invasions 2012, 7, 29-36. [CrossRef]

35. Ellegaard, M.; Lenau, T.; Lundholm, N.; Maibohm, C.; Friis, S.M.M.; Rottwitt, K.; Su, Y. The fascinating diatom frustule-Can it play a role for attenuation of UV radiation? J. Appl. Phycol. 2016, 28, 3295-3306. [CrossRef]

36. Davey, H.M. Life, Death, and In-Between: Meanings and Methods in Microbiology. Appl. Environ. Microb. 2011, 77, 5571-5576. [CrossRef] [PubMed]

37. Zetsche, E.M.; Meysman, F.J.R. Dead or alive? Viability assessment of micro and mesoplankton. J. Plankton Res. 2012, 34, 493-509. [CrossRef]

38. Cangelosi, G.A.; Meschke, J.S. Dead or Alive: Molecular Assessment of Microbial Viability. Appl. Environ. Microb. 2014, 80, 5884-5891. [CrossRef] [PubMed]

39. United States Coast Guard (USCG). The Facts about the MPN Method. Available online: http: / / mariners.coastguard.dodlive.mil/2015/12/14/12142015-coast-guard-decision-on-use-of-mostprobable-number-method (accessed on 20 July 2016).

40. National Research Council (NRC). Disinfectants and Disinfectant By-Products; National Academy of Sciences: Washington, DC, USA, 1987; p. 212, ISBN 0-309-55504-3.

41. Kim, E.C.; Oh, J.H.; Lee, S.G. Consideration on the maximum allowable dosage of active substance produced by ballast wter management system using electrolysis. J. e-Navig. Marit. Econ. 2016, 4, 88-96. 
42. Halevy, I.; Bachan, A. The geologic history of seawater pH. Science 2017, 355, 1069-1071. [CrossRef] [PubMed]

43. Kelsall, G.H. Hypochlorite electro-generation. I. A parametric study of a parallel plate electrode cell. J. Appl. Electrochem. 1984, 14, 177-186. [CrossRef]

44. Krstajic, N. Hypochlorite production II. Direct electrolysis in a cell divided by anionic membrane. J. Appl. Electrochem. 1991, 21, 637-641. [CrossRef]

45. Cha, H.G.; Seo, M.H.; Lee, H.Y.; Lee, J.Y.; Lee, D.S.; Shin, K.; Choi, K.Y. Enhancing the efficacy of electrolytic chlorination for ballast water treatment by adding carbon dioxide. Mar. Pollut. Bull. 2015, 95, 315-323. [CrossRef] [PubMed]

46. Jeong, J.; Kim, C.; Yoon, J. The effect of electrode material on the generation of oxidants and microbial inactivation in the electrochemical disinfection processes. Water Res. 2009, 43, 895-901. [CrossRef] [PubMed]

47. Lacasa, E.; Tsolaki, E.; Sbokou, Z.; Rodrigo, M.A.; Mantzavinos, D.; Diamadopoulos, E. Electrochemical disinfection of simulated ballast water on conductive diamond electrodes. Chem. Eng. J. 2013, 223, 516-523. [CrossRef]

48. Morris, J.C. The acid ionization constant of $\mathrm{HOCl}$ from $5^{\circ}$ to $35^{\circ}$. J. Phys. Chem. 1966, 70, 3798-3805. [CrossRef]

49. Delacroix, S.; Vogelsang, C.; Tobiesen, A.; Liltved, H. Disinfection by-products and ecotoxicity of ballast water after oxidative treatment. Results and experiences from seven years of full-scale testing of ballast water management systems. Mar. Pollut. Bull. 2013, 73, 26-36. [CrossRef] [PubMed]

50. Gonsior, M.; Mitchelmore, C.; Heyes, A.; Harir, M.; Richardson, S.D.; Petty, W.T.; Wright, D.A.; Kopplin, P.S. Bromination of marine dissolved organic matter following full scale electrochemical ballast water disinfection. Environ. Sci. Technol. 2015, 49, 9048-9055. [CrossRef] [PubMed]

51. Song, Y.; Dang, K.; Chi, H.; Guan, D. Corrosion of marine carbon steel by electrochemically treated ballast water. J. Mar. Eng. Technol. 2009, 8, 49-55. [CrossRef]

52. United States Coast Guard (USCG). Ballast Water Treatment Corrosion Scoping Study. Available online: http:/ / www.dtic.mil/docs / citations / ADA613422 (accessed on 15 August 2016).

53. Baere, K.D.; Verstraelen, H.; Rigo, P.; Passel, S.V.; Lenaerts, S.; Potters, G. Study on alternative approaches to corrosion protection of ballast tanks using an economic model. Mar. Struct. 2013, 32, 1-17. [CrossRef]

54. Kahkonen, E.; Nordstrom, K. Toward a nontoxic poison: Current trends in (European Union) biocides regulation. Integr. Environ. Assess. Manag. 2008, 4, 471-477. [CrossRef] [PubMed]

55. European Union. Regulation (EU) No 528/2012 of the European Parliament and of the Council. Concerning the Making Available on the Market and Use of Biocidal Products. Available online: https:/ /www.echa. europa.eu/documents/10162/17158507/consolidated_bpr_en.pdf (accessed on 27 July 2017).

56. International Maritime Organization (IMO). Procedure for Approval of Ballast Water Management Systems that Make Use of Active Substances (G9). Available online: http: / / www.imo.org/blast/blastDataHelper. asp?data_id=22479\&filename=169\%2857\%29.pdf (accessed on 1 August 2017).

57. United States Coast Guard (USCG). Evaluation of Biocides for Potential Treatment of Ballast Water. Available online: http:/ / www.dtic.mil/dtic/tr/fulltext/u2/a429663.pdf (accessed on 1 August 2017).

58. International Maritime Organization (IMO). List of Ballast Water Management Systems that Make Use of Active Substances Which Received Basic and Final Approval. Available online: http:/ /www.imo.org/en/ OurWork/Environment/BallastWaterManagement/Documents/BWM.2-CIRC.34-REV.4.pdf (accessed on 1 August 2017).

59. Anastas, P.T.; Kirchhoff, M.M. Origins, current status, and future challenges of green chemistry. Acc. Chem. Res. 2002, 35, 686-694. [CrossRef] [PubMed]

60. Ashraf, M.A.; Ullah, S.; Ahmad, I.; Qureshi, A.K.; Balkhairf, K.S.; Rehmang, M.A. Green biocides, a promising technology: Current and future applications to industry and industrial processes. J. Sci. Food Agric. 2014, 94, 388-403. [CrossRef] [PubMed]

61. Galindo, C.L.; Garrido, M.C.; Casanueva, J.F.; Nebot, H. Degradation models and ecotoxicity in marine waters of two antifouling compounds: Sodium hypochlorite and an alkylamine surfactant. Sci. Total Environ. 2010, 408, 1779-1785. [CrossRef] [PubMed]

62. Gregg, M.D.; Hallegraeff, G.M. Efficacy of three commercially available ballast water biocides against vegetative microalgae, dinoflagellate cysts and bacteria. Harmful Algae 2007, 6, 567-584. [CrossRef] 
63. Arehmouch, L.; Ghillebaert, F.; Chaillou, C.; Roubaud, P. Lethal effects of Mexel 432 an antifouling agent on embryolarval development of Common Carp (Cyprinus carpio L.). Ecotoxicol. Environ. Saf. 1999, 42, 110-118. [CrossRef] [PubMed]

64. Coulon, I.D.; Bordenave, S.A.; Doumenc, D.; Khalanski, M. Cytotoxicity assessment of antibiofouling compounds and by-products in marine bivalve cell cultures. Toxicol. In Vitro 2000, 14, 245-251. [CrossRef]

65. Wright, D.A.; Dawson, R.; Orano-Dwason, C.E. Shipboards trials of menadione as a ballast water treatment. Mar. Technol. 2007, 44, 68-76.

66. Wright, D.A.; Dawson, R.; Caceres, V.; Dawson, C.E.O.; Kananen, G.E.; Cutler, S.J.; Cutler, H.G. Shipboard testing of the efficacy of SeaKleen as a ballast water treatment to eliminate non-indigenous species aboard a working tanker in Pacific waters. Environ. Technol. 2009, 30, 893-910. [CrossRef] [PubMed]

67. Carbona, S.L.; Frosen, S.V.; Masson, D.; Sassi, J.; Pineau, S.; Lehtiniemi, M.; Corroler, D. Efficacy and environmental acceptability of two ballast water treatment chemicals and an alkylamine based-biocide. Sci. Total Environ. 2010, 409, 247-255. [CrossRef] [PubMed]

68. Qu, Q.; Jiang, S.; Li, L.; Bai, W.; Zhou, J. Corrosion behavior of cold rolled steel in peracetic acid solutions. Corros. Sci. 2008, 50, 35-40. [CrossRef]

69. Li, L.; Qu, Q.; Bai, W.; Chen, Y.; Zhang, S.; Gao, G.; Ding, Z. Effect of $\mathrm{NaCl}$ on the corrosion of cold rolled steel in peracetic acid solution. Int. J. Electrochem. Sci. 2012, 7, 3773-3786.

70. Pohanish, R.P. HazMat Data: For First Response, Transportation, Storage, and Security, 2nd ed.; John Wiley and Sons: Hoboken, NJ, USA, 2004; p. 1263.

71. Cui, Y.T.; Teo, S.L.M.; Leong, W.; Chai, C.L.L. Searching for environmentally-benign antifouling biocides. Int. J. Mol. Sci. 2014, 15, 9255-9284. [CrossRef] [PubMed]

72. Joshi, M.; Mukherjee, A.; Misra, S.C.; Ramesh, U.S. Need of natural biocides in antifouling paints for prevention of marine pollution. Int. J. Innov. Med. Res. Dev. 2015, 4, 43-49.

73. Ruiz, G.M.; Carlton, J.T.; Grosholz, E.D.; Hines, A.H. Global invasions of marine and estuarine habitats by non-indigenous species: Mechanisms, extent, and consequences. Am. Zool. 1997, 37, 621-632. [CrossRef]

74. Vorkapic, A.; Komar, I.; Mrcelic, G.J. Shipboard Ballast Water Treatment Systems on Seagoing Ships. Trans. Marit. Sci. 2016, 1, 19-28. [CrossRef]

75. Elton, C. A new invader. J. Anim. Ecol. 1936, 5, 188-192. [CrossRef]

76. Medcof, J.C. Living marine animals in a ship's ballast water. In Proceedings of the National Shellfisheries Association; The National Shellfisheries Association: Waldoboro, ME, USA, 1975.

77. David, B.; Wolfender, J.; Dias, D.A. The pharmaceutical industry and natural products: Historical status and new trends. Phytochem. Rev. 2015, 14, 299-315. [CrossRef]

78. Newmann, D.J.; Cragg, G.M. Natural Products as Sources of New Drugs from 1981 to 2014. J. Nat. Prod. 2016, 79, 629-661. [CrossRef] [PubMed]

79. Blunt, J.W.; Copp, B.R.; Keyzers, R.A.; Munro, M.H.G.; Prinsep, M.R. Marine natural products. Nat. Prod. Rep. 2017, 34, 235-294. [CrossRef] [PubMed]

80. Nicolau, K.C. Organic synthesis: The art and science of replicating the molecules of living nature and creating others like them in the laboratory. Proc. Math. Phys. Eng. Sci. 2014, 470. [CrossRef] [PubMed]

81. Maier, M.E. Design and synthesis of analogues of natural products. Org. Biomol. Chem. 2015, 13, 5302-5343. [CrossRef] [PubMed]

(C) 2017 by the authors. Licensee MDPI, Basel, Switzerland. This article is an open access article distributed under the terms and conditions of the Creative Commons Attribution (CC BY) license (http://creativecommons.org/licenses/by/4.0/). 